\title{
DIFFERENTIATION OF FLUORESCENT PSEUDOMONADS BY THEIR EFFECT ON MILK AGAR
}

\author{
Mary T. Reynolds, F. R. Falkiner, Roberta Hardy and C. T. Keane \\ Department of Clinical Microbiology, Trinity College, Adelaide Hospital, Peter Street, Dublin 8
}

A PART from some phytopathogens, the fluorescent group of pseudomonads comprises Pseudomonas aeruginosa, $P$. fluorescens and $P$. putida. P. aeruginosa is the commonest and most clinically significant species. The other two species are occasionally associated with serious infections (Gilardi, 1972 and 1976; Martin, Maker and Washington, 1973) but, more significantly, they may be confused with P. aeruginosa in the laboratory (Falkiner, Keane and Taylor, 1974).

Brown and Scott-Foster (1970) devised a simple milk medium to distinguish between $P$. aeruginosa and $P$. fluorescens. Colonies of $P$. aeruginosa were surrounded by a clear zone due to hydrolysis of the casein, and formed a green pigment that diffused into the medium. We report our experience of this medium for the differentiation of fluorescent pseudomonads.

\section{MATERIALS AND METHODS}

Bacterial strains. A study of pseudomonas infections in the seven hospitals served by this laboratory was started in $1971 ; 3800$ isolates of $P$. aeruginosa were collected in 7 years. Eighteen strains of $P$. aeruginosa that did not produce pyocyanin on Diagnostic Sensitivity Test Agar (DST, Oxoid) and Cetrimide Agar (Pseudosel, BBL) were included in the present study because only these strains require further identification. Forty-six isolates of $P$. putida and 21 of $P$. fluorescens were collected from the same seven hospitals and one reference strain of $P$. fluorescens, strain NCTC10038, was included in this study.

Culture media and methods. Antibiotic sensitivities were determined by a modified KirbyBauer method and Multodiscs (Oxoid) on DST agar. The ability of strains to grow at $42^{\circ} \mathrm{C}$ was determined by incubating a nutrient-broth culture, freshly-seeded from a colony on solid medium, at $42^{\circ} \mathrm{C}$ in a waterbath overnight and subculturing twice at 24-h intervals into nutrient broth held at $42^{\circ} \mathrm{C}$.

Lecithinase production was indicated by the development of a zone of turbidity around colonies on Nutrient Agar (Oxoid) containing 10\% Egg Yolk Emulsion (Oxoid) within 5 days. Hydrolysis of gelatin was indicated by the release of charcoal from Charcoal-Gelatin Discs (Oxoid) in heavily-seeded Nutrient Broth No. 2 (Oxoid) after incubation at $37^{\circ} \mathrm{C}$ for $72 \mathrm{~h}$. Ammonium Salt Sugars (Difco) containing ethanol, glucose and mannitol were used to confirm the identity of the fluorescent pseudomonads (King and Phillips, 1978).

Fluorescein production was demonstrated by fluorescence on DST and Pseudosel Agar under an ultraviolet lamp and pyocyanin production was detected in King's " $\mathrm{A}$ " medium (Pseudomonas Agar P, Difco; King, Ward and Raney, 1954).

Preparation and use of milk medium. The milk agar was prepared as described by Brown and Scott-Foster (1970) except that Dairy Bawn Defatted Milk Granules (Mitchelstown Creamery) were used instead of Marvel (Cadbury); the formulations of these products were identical (manufacturers' specifications). The plates were seeded in the normal manner and incubated at $37^{\circ} \mathrm{C}$ for $24 \mathrm{~h}$ and then at room temperature for another $48 \mathrm{~h}$. The procedure was repeated with incubation at $37^{\circ} \mathrm{C}$ for $72 \mathrm{~h}$, and also with a modified milk medium that contained $25 \%$ nutrient broth. The plates were examined at $24-h$ intervals and the results scored as,+++ or \pm , for clearing around colonies (casein hydrolysis) and + or \pm for pigment production.

Received 15 Nov. 1978; accepted 8 Jan. 1979.

J. MED. MCROBIOL. - VOL. 12 (1979) 


\section{RESULTS \\ Identification of the fluorescent pseudomonads}

All the isolates were gram-negative, oxidase-positive bacilli that grew on cetrimide agar and fluoresced under ultraviolet illumination. The 18 strains of $P$. aeruginosa produced pyocyanin only on King's " $A$ " medium and most of them had the characteristic odour of trimethylamine. Most of them were resistant to kanamycin and sensitive to carbenicillin. Conversely $P$. fluorescens and $P$. putida were sensitive to kanamycin and resistant to carbenicillin (table I). This difference is the first indication in the routine laboratory whether a fluorescent pseudomonad is $P$. aeruginosa or one of the other two species; only five isolates of $P$. aeruginosa from two patients out of the total of more than $\mathbf{3 8 0 0}$ were sensitive to kanamycin and resistant to carbenicillin and they produced pyocyanin.

The results of the tests used to differentiate the fluorescent pseudomonads are shown in table I. The Computer Trials Laboratory, Central Public Health Laboratory, Colindale kindly confirmed the identity of some of the strains.

\section{TABLE I}

Results of tests used to differentiate between the fluorescent pseudomonads

\begin{tabular}{|c|c|c|c|}
\hline \multirow[b]{2}{*}{ Test } & \multicolumn{3}{|c|}{ Results obtained with } \\
\hline & P. aeruginosa & P. fluorescens & P. putida \\
\hline $\begin{array}{l}\text { Antimicrobial susceptibilities to } \\
\text { carbenicillin } \\
\text { polymixin } \\
\text { gentamicin } \\
\text { kanamycin }\end{array}$ & $\begin{array}{l}\mathbf{S}^{*} \\
\mathbf{S} \\
\mathbf{S} \\
\mathbf{R}\end{array}$ & $\begin{array}{l}\mathbf{R} \\
\mathbf{S} \\
\mathbf{S} \\
\mathbf{S}\end{array}$ & $\begin{array}{l}\mathbf{R} \\
\mathbf{S} \\
\mathbf{S} \\
\mathbf{S}\end{array}$ \\
\hline $\begin{array}{l}\text { Production of pigment other than } \\
\text { fluorescein on King's "A" medium } \\
\text { Growth at } 42^{\circ} \mathrm{C} \\
\text { Production of lecithinase } \\
\text { Hydrolysis of gelatin }\end{array}$ & $\begin{array}{l}+ \\
+ \\
\bar{v}\end{array}$ & $\begin{array}{l}- \\
\overline{+} \\
+\end{array}$ & $\begin{array}{l}- \\
- \\
-\end{array}$ \\
\hline $\begin{array}{l}\text { Fermentation of ammonium salt sugars } \\
\text { ethanol } \\
\text { glucose } \\
\text { mannitol }\end{array}$ & $\begin{array}{l}+ \\
+ \\
+\end{array}$ & $\begin{array}{l}- \\
+ \\
+\end{array}$ & $\begin{array}{l}v \\
+ \\
-\end{array}$ \\
\hline
\end{tabular}

$\mathbf{S}=$ Sensitive; $\mathbf{R}=$ resistant + = positive reaction; $-=$ negative reaction; $\mathbf{V}=$ variable reaction.

$* 85 \%$ of $P$. aeruginosa were sensitive to carbenicillin; $98 \%$ were sensitive to gentamicin.

\section{Hydrolysis of casein by fluorescent pseudomonads}

The results obtained with the milk medium incubated at $37^{\circ} \mathrm{C}$ for $72 \mathrm{~h}$ are shown in table II. Most ( $72 \%$ ) of the $P$. aeruginosa strains produced pigment in $72 \mathrm{~h}$ although pigmentation was poor when compared with a control strain of $P$. aeruginosa and with 80 well-pigmented strains that were tested in a previous study (unpublished data). In no case was pigmentation strong enough to warrant a ++ score. Many $(59 \%)$ of the $P$. fluorescens strains also produced the yellow pigment fluorescein; it was difficult to distinguish this from pigmentation produced by some strains of $P$. aeruginosa that produced only a small amount of pyocyanin. Approximately the same proportions of the $P$ fluorescens $(82 \%)$ and $P$. aeruginosa $(83 \%)$ strains hydrolysed casein. $P$. putida did not produce obvious amounts of fluorescein or hydrolyse casein.

Brown and Scott-Foster (1970) found that the addition of $25 \%$ nutrient broth to the milk in the medium gave improved hydrolysis and pigmentation after $24 \mathrm{~h}$. They also noted an improvement in pigmentation when the plates were incubated at $37^{\circ} \mathrm{C}$ for $24 \mathrm{~h}$ and then $20^{\circ} \mathrm{C}$ for 
TABLE II

The hydrolysis of casein and pigment production by fluorescent pseudomonads on milk-agar medium

\begin{tabular}{|c|c|c|c|c|c|c|c|c|c|}
\hline \multirow{3}{*}{\multicolumn{2}{|c|}{$\begin{array}{c}\text { Graded }( \pm,+,++) \\
\text { positive reaction } \\
\text { at } 24,48 \text { and } \\
72 \mathrm{~h} \text { at } 37^{\circ} \mathrm{C}\end{array}$}} & \multicolumn{8}{|c|}{ Number of strains $(\%)$ of the given species that gave the stated reaction } \\
\hline & & \multicolumn{3}{|c|}{ P. aeruginosa (18 strains) } & \multicolumn{3}{|c|}{ P. fluorescens (22 strains) } & \multicolumn{2}{|c|}{ P. putida (46 strains) } \\
\hline & & \multirow{2}{*}{$\begin{array}{l}\begin{array}{c}\text { casein } \\
\text { hydrolysis }\end{array} \\
7\}(67 \%)\end{array}$} & \multicolumn{2}{|c|}{$\begin{array}{c}\text { pigment } \\
\text { production }\end{array}$} & \multicolumn{2}{|c|}{$\begin{array}{c}\text { casein } \\
\text { hydrolysis }\end{array}$} & \multirow{2}{*}{$\begin{array}{c}\begin{array}{c}\text { pigment } \\
\text { production }\end{array} \\
3 \\
3 \\
3\end{array}(27 \%)$} & \multirow{2}{*}{$\begin{array}{c}\begin{array}{c}\text { casein } \\
\text { hydrolysis }\end{array} \\
0 \\
0 \\
0\end{array}$} & \multirow{2}{*}{$\begin{array}{c}\begin{array}{c}\text { pigment } \\
\text { production }\end{array} \\
0 \\
0 \\
0\end{array}$} \\
\hline 24 hours & $\begin{array}{r} \pm \\
+ \\
+\end{array}$ & & $\left.\begin{array}{l}3 \\
6 \\
0\end{array}\right\}$ & $(50 \%)$ & $\begin{array}{l}5 \\
5 \\
0\end{array}$ & $(45 \%)$ & & & \\
\hline 48 hours & $\begin{array}{r} \pm \\
+ \\
+\end{array}$ & $\left.\begin{array}{l}3 \\
7 \\
4\end{array}\right\}(78 \%)$ & $\begin{array}{r}0 \\
10 \\
0\end{array}$ & $(56 \%)$ & $\left.\begin{array}{r}1 \\
13 \\
1\end{array}\right\}$ & $(68 \%)$ & $\begin{array}{l}3 \\
7 \\
0\end{array}(45 \%)$ & $\begin{array}{l}0 \\
0 \\
0\end{array}$ & $\begin{array}{l}0 \\
0 \\
0\end{array}$ \\
\hline 72 hours & $\begin{array}{r} \pm \\
+ \\
+\end{array}$ & $\left.\begin{array}{c}0 \\
5 \\
10\end{array}\right\}(83 \%)$ & $\begin{array}{r}0 \\
13 \\
0\end{array}$ & $(72 \%)$ & $\left.\begin{array}{l}2 \\
8 \\
8\end{array}\right\}$ & $(82 \%)$ & $\underset{0}{2}\}_{0}^{2}(59 \%)$ & $\begin{array}{l}0 \\
0 \\
0\end{array}$ & $\begin{array}{l}0 \\
0 \\
0\end{array}$ \\
\hline
\end{tabular}

$24 \mathrm{~h}$. In the present study however neither the addition of $25 \%$ broth nor incubation of the plates at room temperature after the initial incubation at $37^{\circ} \mathrm{C}$ significantly affected casein hydrolysis or pigmentation. Green pigment produced by $P$. aeruginosa rarely diffused into the milk medium either in this study or previously when 80 strains of normally pigmented $P$. aeruginosa were tested.

\section{Discussion}

In general, $P$. aeruginos $a$ is readily identified by its characteristic odour and green pigmentation on routine laboratory media. However, the strains that are poorly pigmented on ordinary media require further identification, and for epidemiological reasons it is necessary to distinguish between these organisms and $P$. fluorescens and $P$. putida. According to King and Phillips (1978) P. fluorescens does not hydrolyse casein, but this statement was the result of a transcription error in their report (Professor I. Phillips, personal communication); P. fluorescens strains did hydrolyse casein in their tests. Gilardi (1976) found that all $P$. fluorescens strains and $60 \%$ of $P$. aeruginos $a$ strains hydrolysed casein. Our results also suggest that hydrolysis of casein is not a suitable characteristic for differentiation between $P$. aeruginosa and $P$. fluorescens. Furthermore we do not consider that pyocyanin production is a reliable characteristic, except on King's " $A$ " medium; it is particularly unreliable in poorly pigmented strains because pigmentation is affected by environmental conditions, especially aeration.

The marked discrepancy between our findings and those of Brown and Scott-Foster (1970) may be explained by the small numbers and origin of their test strains, which were mostly reference strains.' The strains used in the present study were, with one exception, clinical isolates.

We conclude that the scheme of Phillips (1969) should be used for the routine identification of strains of $P$. aeruginosa that are not obvious pigment producers. The distinction between $P$. fluorescens and $P$. putida is less straightforward but the important differences are the production of gelatinase and lecithinase and the hydrolysis of casein by $P$. fuorescens.

\section{SUMMARY}

Eighty-six clinical isolates of fluorescent pseudomonads that did not produce pyocyanin on Diagnostic Sensitivity Test Agar or Cetrimide Agar were identified on the basis of their antibiotic sensitivity, production of pigment on King's " $A$ " medium, growth at $42^{\circ} \mathrm{C}$, production of lecithinase and hydrolysis of gelatin. The identity of the strains was confirmed in tests 
with the ammonium salt sugars ethanol, glucose and mannitol. These tests were adequate for distinguishing between the three important fluorescent pseudomonads.

The detection of casein hydrolysis on milk agar was assessed as a rapid method of distinguishing $P$. aeruginosa from the other species of fluorescent pseudomonads but proved unhelpful when compared with, or included in, a small set of tests. Most strains of $P$. aeruginosa and $P$. fluorescens hydrolysed casein.

\section{REFERENCES}

Brown, M. R. W. AND Scott-Foster, J. H. 1970. A simple diagnostic milk medium for Pseudomonas aeruginosa . J. clin. Path., 23, 172.

Falkiner, F. R., Keane, C. T. AND TAYlor, M. R. H. 1974. Contamination of urine specimens with Pseudomonas putida and Pseudomonas fluorescens. Proc. Soc. gen. Microbiol., 2, 15.

GILARDI, G. L. 1972. Infrequently encountered Pseudomonas species causing infection in humans. Ann. intern. Med. 77, 211.

Gilardi, G. L. 1976. Pseudomonas species in clinical microbiology. Mt Sinai J. Med., 43, 710.

KING, A. AND PHILLIPS, I. 1978. The identification of pseudomonads and related bacteria in a clinical laboratory. J. med. Microbiol., 11, 165.

KInG, E. O., WARD, M. K. AND RANEY, D. E. 1954. Two simple media for the demonstration of pyocyanin and fluorescin. J. lab. clin. Med., 44, 301.

Martin, W. J., Maker, M. D. AND Washington, J. A. 1973. Bacteriology and in vitro antimicrobial susceptibility of the Pseudomonas fluorescens group isolated from clinical specimens. Am. J. clin. Path., 60, 831.

PhILliPS, I. 1969. Identification of Pseudomonas aeruginosa in the clinical laboratory. J. med. Microbiol., 2, 9. 